\title{
Anti-inflammatory and ECM gene expression modulations of $\beta$-eudesmol via NF-KB signaling pathway in normal human dermal fibroblasts
}

Kyung Yun Kim

\begin{abstract}
Background: $\beta$-eudesmol is a kind of aromatic compound belonging to sesquiterpenoid which exists within not only the bark of magnolia but also Nardostachys jatamansi, Atractylodes lancea, Pterocarpus santalinus, Ginkgo bilobal, Cryptomeria japonica, etc., and there has been progress in medical and pharmaceutic researches on antitumor, anticancer, and anti-inflammatory effects; nervous system stabilization; and vasodilator effects, etc., but not in researches on skin cares and cosmetics at all. Therefore, this study pretreated $\beta$-eudesmol with human dermal fibroblasts (HDFs) and then gave oxidative stresses with $\mathrm{H}_{2} \mathrm{O}_{2}$ to examine antioxidation, anti-inflammatory, and cell preservation effects. Through this process, it proves the possibility of $\beta$-eudesmol as cosmetic materials.
\end{abstract}

Methods: This study verified the effectiveness of $\beta$-eudesmol through cell viability analysis, reactive oxygen estimation, associated $\beta$-galactosidase assay, nuclear factor-kappa B (NF-kB) luciferase assay, and quantitative real-time polymerase chain reaction (qRT-PCR).

Results: The cell viability which decreased due to $\mathrm{H}_{2} \mathrm{O}_{2}$ increased as per dose-dependent manners of $\beta$-eudesmol. Also, at the 2,2-diphenyl-1-picrylhydrazyl (DPPH) radical scavenging activity assay, intracellular reactive oxygen species (ROS) quantitative analysis and glutathione (GSH) estimation, the relative levels which were changed by $\mathrm{H}_{2} \mathrm{O}_{2}$ treatment, showed attenuated or protective transition forms, depending on the concentration of $\beta$-eudesmol. Additionally, reduced superoxide dismutase 1 (SOD1) and catalase (CAT) gene expression by $\mathrm{H}_{2} \mathrm{O}_{2}$ were increased by $\beta$-eudesmol. As the result of the promoter activity analysis of NF-kB which has a key role in inflammation and skin aging, NF-kB activity decreases as $\beta$-eudesmol concentration increases, and also this study proves that gene expression of interleukin 1 beta (IL-1 $\beta$ ) which is a downstream gene of NF-KB related to inflammatory response decreases as well as tumor necrosis factor-alpha (TNF- $\alpha$ ) gene expression depending on the concentration of $\beta$-eudesmol.

Conclusions: Through these results, this study suggests there are anti-inflammatory effects by shutting out the NF-kB pathway. Following the results of the extracellular matrix (ECM) regulating gene expression analysis, this study proves that oxidative stress-induced increased MMP1 levels were decreased depending on the concentration of $\beta$-eudesmol and verifies that it hinders the collapse of collagen through inhibition of transcriptional activity of NF-kB. From the result of $\beta$-eudesmol regulating tissue inhibitors of metalloproteinase (TIMP)-1 gene expression which hinders matrix metalloproteinase (MMP), activation and alteration of gene expression of collagen type I alpha 1 (COL1A1) underpins the above consequences. Through this research, it is considered that $\beta$-eudesmol as one of natural cosmetic materials with such effects as antioxidation, anti-inflammation, and cell preservation is worthy of notice.

Keywords: $\beta$-eudesmol, Antioxidant, Anti-inflammation, Cellular senescence, Fibroblast, Extra cellular matrix 


\section{Background}

The bark of magnolia and magnolia obovata which is the dried rhizodermis have been used as a traditional medicine for medical treatment of bronchitis, asthma, stomach disease, emotional instability disorder, and allergy in Korea, Japan, and China (Hoang et al. 2010). On the basis of this folk remedy, the research on central sedation of central nervous system through magnolia bark extract was reported in 1973 (Watanabe et al. 1973). Various biologically active substances extracted from the bark and rhizodermis of magnolia are essential oils such as $\beta$-eudesmol, $\alpha$-pinenes, $\beta$-pinenes, and bornyl acetate and diphenyl compounds such as magnolol, honokiol, and alkaloids; magnocurarine; and magnoflorine. It is reported that some of these ingredients has pharmacologic effects on the nervous system (Watanabe et al. 1983; Chiou et al. 1997).

In this experiment, $\beta$-eudesmol is used among those biologically active substances of magnolia, and $\beta$-eudesmol is a kind of aromatic compound belonging to sesquiterpenoid which exists not only in the bark of magnolia but also in medical herbs such as Nardostachys jatamansi, Atractylodes lancea, Pterocarpus santalinus, Ginkgo biloba, and Cryptomeria japonica etc. (Li et al. 2013), and its chemical formula is $\mathrm{C}_{15} \mathrm{H}_{26} \mathrm{O}$ and its molecular mass is 222 . $\beta$ eudesmol has antimutagenic effects (Miyazawa et al. 1996) and nervous system sedation effects too. It has been proved that $\beta$-eudesmol has effects to shut off nicotinic acetylcholine receptor in the neuromuscular junction (Kimura et al. 1991), to control neuromuscular disorder caused by neostigmine (Chiou and Chang 1992), and to control activities of $\mathrm{Na}^{+}, \mathrm{K}^{+}$-ATPase, and $\mathrm{H}^{+}$(Satoh et al. 1992). Also, it has been reported that $\beta$-eudesmol controls fatal toxicity caused by organophosphorus compound (Chiou et al. 1995), induces outgrowing of neurite in pheochromocytoma (PC12) cells through activation of mitogen-activated protein kinases (MAPK) (Obara et al. 2002), and has vasodilator effects through shutting off adrenaline $\alpha-1$ receptor (Lim and Kee 2005). It has been reported that $\beta$-eudesmol controls interleukin (IL)- 6 and receptor interacting protein-2 in mast cell, activates p38 MAPK, and has anti-inflammation effects through process to control caspase-1 (Seo et al. 2011). Recently, researches on effectiveness of $\beta$-eudesmol to blood vessels on the nervous system and also antitumor and anticancer effects have been largely in progress. Apoptotic effect through neovascular control effect of $\beta$-eudesmol has been reported (Ikeda and Nagase 2002; Ma et al. 2008). And it has been proved that $\beta$-eudesmol has apoptotic effect through caspase- 3 via caspase- 9 caused by cytochrome in HL-60 cells (Hoang et al. 2010), c-Jun N-terminal kinase (JNK)dependent apoptotic effect through mitochondria passage in HL-60 cells (Li et al. 2013), and anticancer effects in the experiment of nude mouse to whom it implanted through the method of heterotransplantation of human cholangiocarcinoma (Plengsuriyakarn et al. 2015).

Looking at existing studies on $\beta$-eudesmol, there have been reports about medical and pharmacologic researches on its anti-inflammation, antimutagenicity, nervous system stabilization, vasodilator, antitumor, and anticancer effects (Li et al. 2013; Miyazawa et al. 1996; Kimura et al. 1991; Chiou and Chang 1992; Satoh et al. 1992; Chiou et al. 1995; Obara et al. 2002; Lim and Kee 2005; Seo et al. 2011; Ikeda and Nagase 2002; Ma et al. 2008; Plengsuriyakarn et al. 2015). However, research on the mechanism of $\beta$ eudesmol in human dermal fibroblast has not been reported yet, and also, there have been no researches on $\beta$ eudesmol as skin care and cosmetic compounds. Therefore, this research intends to verify antioxidation, antiinflammation, and cell preservation effects of $\beta$-eudesmol in human dermal fibroblast through studying the intracellular mechanism. Therefore, this study aims to suggest possibility of $\beta$-eudesmol as natural cosmetic materials.

\section{Methods \\ Cell culture}

For this research, we purchased and used human dermal fibroblasts (HDFs) from Lonza Inc. (Basel, Switzerland) and cultured it using Dulbecco's modified Eagle's medium (DMEM; Hyclone, Logan, UT, USA) as culture medium which contains $10 \%$ fetal bovine serum (FBS; Hyclone) and $1 \%$ penicillin/streptomycin (penicillin $100 \mathrm{IU} / \mathrm{mL}$, streptomycin $100 \mu \mathrm{g} / \mathrm{mL}$; Invitrogen/Life Technologies, Carlsbad, CA, USA). Cultured cells within an incubator where we kept in a temperature of $37{ }^{\circ} \mathrm{C}$ and $5 \% \mathrm{CO}_{2}$.

\section{Sample treatment}

We purchased $\beta$-eudesmol in the form of powder which is refined (>90\%) from Sigma-Aldrich Inc. (St. Louis, MO, USA). When we used it in the experiment, we dissolved it in dimethyl sulfoxide (DMSO; Sigma-Aldrich) in optimal concentration. After, we cultured HDFs $\left(1 \times 10^{6}\right.$ cells/well $)$ in a $60-\mathrm{mm}$ cell culture dish for $24 \mathrm{~h}$; we added $\beta$ eudesmol as per indicated concentration to the culture medium and pretreated for $24 \mathrm{~h}$, treated $\mathrm{H}_{2} \mathrm{O}_{2}$ in an appropriate concentration, and then used them for analysis after $3 \mathrm{~h}$. For the experiment of gene level, after culturing HDFs $\left(2 \times 10^{5}\right.$ cells/well $)$ in a cell culture medium, we treated $\beta$-eudesmol as per indicated concentration for $24 \mathrm{~h}$ when the plate's density is more than $85-90 \%$. We treated $\mathrm{H}_{2} \mathrm{O}_{2}$ and collected cells after $3 \mathrm{~h}$, and from these cells, we extracted RNA; then on the basis of this RNA, we identified gene expression through quantitative real-time polymerase chain reaction (qRT-PCR).

\section{Cell viability estimation}

We used the principle of water-soluble tetrazolium salt (WST-1) assay for evaluating cell viability. After we 
inoculated each HDF of $100 \mu \mathrm{L}$ in density of $3 \times 10^{3}$ cells/ well in 96-well plates and cultured for $24 \mathrm{~h}$, we treated $\mathrm{H}_{2} \mathrm{O}_{2}$ and every kind of sample, in cell culture plates. After we added $10 \mu \mathrm{L}$ of EZ-Cytox cell viability assay kit reagent (ItsBio, Seoul, Korea) in the cultured cell and cultured for $1 \mathrm{~h}$, we used a microplate reader (Bio-Rad, Hercules, CA, USA) to estimate absorbance in the scale of $490 \mathrm{~nm}$ and repeated three times and deduced the average value and standard deviation of cell viability.

\section{cDNA manufacturing}

After using Trizol reagent (Invitrogen/Life Technologies) to dissolve cells which we obtained through cell culture, we added $0.2 \mathrm{~mL}$ of chloroform (Biopure, Tulln, Austria) and then centrifuged for $20 \mathrm{~min}$ at $12,000 \mathrm{rpm}$ at $4{ }^{\circ} \mathrm{C}$ to divide into pellets which include protein and supernatant which include mRNA. For the supernatant, we added $0.5 \mathrm{~mL}$ of isopropanol (Biopure) and left at room temperature for $10 \mathrm{~min}$, and then centrifuged it at $12,000 \mathrm{rpm}$ at $4{ }^{\circ} \mathrm{C}$ to precipitate RNA. Next, we used $75 \%$ ethanol to wash, and then we removed ethanol and dried at room temperature. We dissolved dried RNA in diethylpyrocarbonate (DEPC; Biopure) water, and among the extracted RNA, we only used pure RNA whose purity is more than a ratio 1.8 of $260 / 280 \mathrm{~nm}$ using Nanodrop (Maestrogen, Las Vegas, NV, USA).

For cDNA synthesis, we manufactured total $10 \mu \mathrm{L}$ of $1 \mu \mathrm{g}$ RNA, $0.5 \mathrm{ng}$ oligo dT18, and DEPC water in a PCR tube, and then we treated them for $10 \mathrm{~min}$ at the degree of $70{ }^{\circ} \mathrm{C}$ to induce RNA denaturation. Next, we used M-MLV reverse transcriptase (Enzynomics, Dajeon, Korea) to react for $1 \mathrm{~h}$ at $37^{\circ} \mathrm{C}$ to synthesize cDNA.

\section{Quantitative real-time PCR}

To analyze gene expression pattern quantitatively within HDFs caused by $\beta$-eudesmol, we used qRT-PCR method. The qRT-PCR is to synthesize $0.2 \mu \mathrm{M}$ primers, $50 \mathrm{mM}$ $\mathrm{KCl}, 20 \mathrm{mM}$ Tris/HCl pH 8.4, $0.8 \mathrm{mM}$ dNTP, $0.5 \mathrm{U}$ Taq DNA polymerase, $3 \mathrm{mM} \mathrm{MgCl}_{2}$, and $1 \times$ SYBR green (Invitrogen/Life Technologies) in a PCR tube to manufacture the reaction solution, and is to use Linegene $\mathrm{K}$ (BioER,
Hangzhou, China). To denature DNA, the mixture is heated for $3 \mathrm{~min}$ at $94{ }^{\circ} \mathrm{C}$, and then 40 cycles of denaturation $\left(94{ }^{\circ} \mathrm{C}, 30 \mathrm{~s}\right)$, annealing $\left(58{ }^{\circ} \mathrm{C}, 30 \mathrm{~s}\right)$, and polymerization $\left(72{ }^{\circ} \mathrm{C}, 30 \mathrm{~s}\right)$ were performed. We used SYBR green to identify changing of each gene expression and verified effectiveness of PCR through the melting curve. We standardized expression of $\beta$-actin for comparative analysis on each gene expression. The primer used in the experiment is shown in Table 1.

\section{DPPH radical scavenging activity assay}

DPPH assay is a method to inject a sample diluent of $100 \mu \mathrm{L}$ of each concentration respectively on a 96-well plate and add $50 \mu \mathrm{L}$ of DPPH of $0.2 \mathrm{mM}$, and then shut off the light at room temperature and neglect it for $30 \mathrm{~min}$. We used a microplate reader (Bio-Rad) to estimate absorbance caused by DPPH reduction in the scale of $514 \mathrm{~nm}$ and repeated to perform estimation three times and deduced average value and standard deviation of absorbance.

\section{Intracellular reactive oxygen species (ROS) quantitative analysis}

To estimate the changing of concentration of ROS within cells, we inoculated HDFs of $2 \times 10^{5}$ cells/well in a $60-\mathrm{mm}$ culture medium and cultured for $24 \mathrm{~h}$ and afterwards we treated cells properly and then cultured for $24 \mathrm{~h}$. Then we added $10 \mu \mathrm{M}$ of dichlorofluorescein diacetate (DCF-DA; Sigma-Aldrich) which is needed to estimate ROS within cells and cultured for $30 \mathrm{~min}$. Subsequently, we added phosphate buffered saline (PBS) to obtained cells and set them free; finally, we estimated amount of changing of ROS by using a flow cytometer (BD Biosciences, San Jose, CA, USA). To verify ROS scavenging effects of $\beta$-eudesmol, we also treated L-ascorbic acid which acts as an ROS scavenger, and then we estimated through the same process.

\section{Glutathione (GSH) estimation}

As an indicator for toxicity reaction inducing apoptotic and oxidative stress, GSH level change has been estimated (Esposito et al. 2000; Zhang et al. 2010; Kil et al.

Table 1 Lists of primers used in this study

\begin{tabular}{lll}
\hline Gene & Forward primer & Reverse primer \\
\hline$\beta$-actin & GGATTCCTATGTGGGCGACGA & CGCTCGGTGAGGATCTTCATG \\
SOD1 & GGGAGATGGCCCAACTACTG & CCAGTTGACATCGAACCGTT \\
CAT & ATGGTCCATGCTCTCAAACC & CAGGTCATCCAATAGGAAGG \\
TNF- $a$ & CCCAGGGACCTCTCTCTAATC & GGTTGGCTACAACATGGGCTACA \\
IL-1 $\beta$ & GATCCATTCTCCAGCTGCA & CAACCAAGTATTCTCCATG \\
COLIA1 & AGGGCCAAGACGAAGACATC \\
MMP1 & AGATCACGCATCGCACAACA \\
TIMP1 & GGGCTTAGATCATTCCTCAGTGCC & CAGGGTGACACCAGTGACTGCAC \\
\hline
\end{tabular}


2012). We used ThiolTracker ${ }^{\mathrm{TM}}$ Violet Glutathione Detection Reagent (Invitrogen) to estimate the amount of reduced GSH. Before pretreatment of $\beta$-eudesmol for $24 \mathrm{~h}$, HDF cells were seeded as $2 \times 10^{5}$ cells/well in a $60-\mathrm{mm}$ culture dish and cultured for $24 \mathrm{~h}$. Next cells were treated $500 \mu \mathrm{M} \mathrm{H}_{2} \mathrm{O}_{2}$ and cultured for $3 \mathrm{~h}$ more. After we obtained cultured cells, we centrifuged them at $5000 \mathrm{rpm}$ at $4{ }^{\circ} \mathrm{C}$ for 5 min to precipitate cells, and we removed supernatant and set cell pellet free through PBS of $300 \mu \mathrm{L}$. Then we added ThiolTracker $^{\text {TM }}$ Violet dye of $300 \mu \mathrm{L}$ to cells. After blending softly, we cultured in the darkroom at room temperature for $30 \mathrm{~min}$. And then, we washed cells through PBS, and in the condition of $5000 \mathrm{rpm}$ at $4{ }^{\circ} \mathrm{C}$, cells were centrifuged for $5 \mathrm{~min}$ and supernatant removed. Using excitation and emission at 405 and $525 \mathrm{~nm}$ each, a flow cytometer (BD Biosciences) was used to estimate fluorescent value.

\section{Cellular senescence estimation}

We estimated senescence by using senescence-associated beta-galactosidase (SA- $\beta$-gal) assay which is a method using a senescence detection kit (Biovision, Milpitas, CA, USA). After we inoculated HDFs of $2 \times 10^{5}$ cells/well in a $60-\mathrm{mm}$ culture dish and cultured for $24 \mathrm{~h}$, we treated cells properly and cultured for $24 \mathrm{~h}$ more. Then we eliminated a culture medium from the plates and washed with $1 \mathrm{~mL}$ PBS, and added $0.5 \mathrm{~mL}$ fixing solution for $15 \mathrm{~min}$. Next, we added $0.5 \mathrm{~mL}$ mixed staining solution (staining solution $470 \mu \mathrm{L}$, staining supplement $5 \mu \mathrm{L}, 20 \mathrm{mg} / \mathrm{mL} \mathrm{X-gal} \mathrm{in} \mathrm{dimethylfor-}$ mamide (DMF) $25 \mu \mathrm{L}$ ) to each fixed HDFs and cultured for $24 \mathrm{~h}$ at $37{ }^{\circ} \mathrm{C}$. After washing dyed cells with PBS, we estimated numbers of dyed cells through an optical microscope (Olympus, Tokyo, Japan) to analyze senescent cell portion. We calculated the numbers of total cells and dyed cells and figured out the ratio of senescent cells to identify.

\section{NF-кB luciferase assay}

To identify influence of $\beta$-eudesmol on NF-кB activity, we used NF- $\mathrm{kB}$ promoter luciferase assay in this experiment. We used NF-kB reporter NIH-3T3 stable cell line (Panomics, Fermont, CA, USA) including reporter gene (luciferase gene) which contains NF- $\mathrm{B}$ promoter consensus sequence at the promoter region. As for the promoter activity of $N F-k B$, the transcription factor is proportional to the amount of luciferase gene expression; therefore, through this, we identified activity of such a transcription factor as NF- $\mathrm{B}$ has an influence on skin inflammatory and skin aging.

After we seeded NF- $\kappa$ B reporter NIH-3T3 stable cell of $2 \times 10^{5}$ cells/well in a $60-\mathrm{mm}$ culture dish and cultured for $24 \mathrm{~h}$, we treated cells in the proper condition like the above experiments, and cultured for $24 \mathrm{~h}$ more. Then we obtained cultured cells, added passive lysis buffer (Promega, Madison, WI, USA), on ice for $10 \mathrm{~min}$ to dissolve; next, we centrifuged for $30 \mathrm{~min}$ in the condition of $12,000 \mathrm{rpm}$ at $4^{\circ}$ $\mathrm{C}$ and collected supernatant. After aliquoting $80 \mu \mathrm{L}$ of the supernatant which contains the same amount of protein in each black 96-well plate, we added and mixed luciferin (Promega) subsequently. Because luciferin is sensitive to the light, we used a Veritas luminometer (Turner Designs, Sunnyvale, CA, USA) to estimate luminance of luciferin right after adding it to the sample.

\section{Statistical process}

All experiments of this research were performed more than three times separately under the same condition to get experimental results, and we used Student's $t$ test for every experiment and analyzed that it is statistically significant when $p$ value of every experimental result is less than 0.05 .

\section{Results}

\section{Cell viability}

After we treated each HDF through $\beta$-eudesmol in various concentrations of $5,10,20,40$, and $80 \mu \mathrm{M}$ and cultured for $24 \mathrm{~h}$, we used WST-1 assay to estimate cell viability. As the result that we identified cell viability, it showed viability of $101,107,98,91$, and $83 \%$, respectively. For concentration of $20 \mu \mathrm{M}$, it hardly had an influence on viability, and it showed that cell viability decreased at the case of treatment through $\beta$-eudesmol in their concentrations of 40 and $80 \mu \mathrm{M}$ (Fig. 1a). After
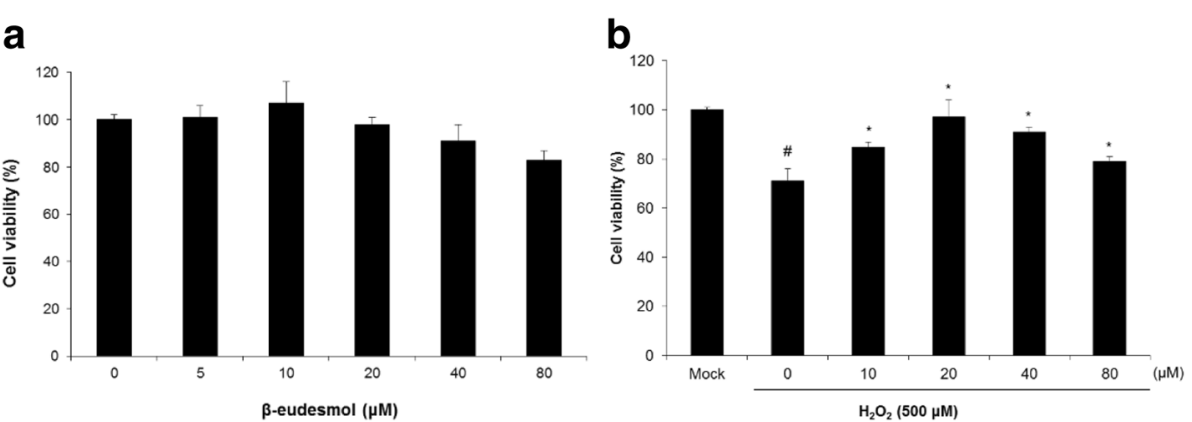

Fig. 1 Cell viability on $\beta$-eudesmol in HDFs. a Cytotoxicity on $\beta$-eudesmol in HDFs. b Cell viability on $\mathrm{H}_{2} \mathrm{O}_{2}$ in the $\mathrm{HDFs}$ pretreated with $\beta$-eudesmol. ( ${ }^{*} p<0.05$ ) 
pretreating HDFs through $\beta$-eudesmol in concentrations of 5,10 , and $20 \mu \mathrm{M}$ respectively for $24 \mathrm{~h}$ and treating with $500 \mu \mathrm{M} \mathrm{H}_{2} \mathrm{O}_{2}$ for $3 \mathrm{~h}$, we made observations of cell viability. Assuming cell viability is $100 \%$, in that case, we did not treat HDFs through both $\beta$-eudesmol and $\mathrm{H}_{2} \mathrm{O}_{2}$, cell viability decreased to $71 \%$ when we did not treat $\mathrm{HDFs}$ through $\beta$-eudesmol but $\mathrm{H}_{2} \mathrm{O}_{2}$ of $500 \mu \mathrm{M}$. However, cell viability was $85 \%$ at the case of pretreatment through $\beta$ eudesmol at $5 \mu \mathrm{M}, 85 \%$ at the case of pretreatment through $\beta$-eudesmol of $10 \mu \mathrm{M}$, and $97 \%$ at the case of pretreatment through $\beta$-eudesmol of $20 \mu \mathrm{M}$; therefore, through this result, we identified that cell viability of HDFs recovered depending on concentrations. On the contrary, cell viability at the case of pretreatment through $\beta$ eudesmol of 40 and $80 \mu \mathrm{M}$ was shown as 91 and $79 \%$ respectively; therefore, we identified that cell viability decreased in concentration more than $40 \mu \mathrm{M}$. So we used concentration of $\beta$-eudesmol to $20 \mu \mathrm{M}$ at the most for HDFs in further experiments (Fig. 1b).

\section{Antioxidative effects of $\beta$-eudesmol}

Using DPPH radical scavenging activity assay, we identified radical scavenging effects of $\beta$-eudesmol. As positive control group, we performed comparative analysis on $\mathrm{N}$-acetyl$\mathrm{L}$-cysteine (NAC) which is known as an ROS scavenger. At the case of treatment through $\beta$-eudesmol in concentrations of 5,10 , and $20 \mu \mathrm{M}$, radical scavenging effects increased to 5,31 , and $49 \%$ respectively depending on concentration. At the case of treatment through NAC as positive control group in concentrations of 5,10 , and $20 \mu \mathrm{M}$, we identified that radical scavenging effects are shown as 8,25 , and $46 \%$ respectively. Identified that $\beta$ eudesmol has similar radical scavenging effects with NAC, it can be admitted that $\beta$-eudesmol has positive radical scavenging effects (Fig. 2a). To identify effects of $\beta$ eudesmol on decrease of total amount of intracellular ROS which occurs in the course of cell metabolism and $\mathrm{H}_{2} \mathrm{O}_{2}$ addition, we used DCF-DA as a fluorescent probe to perform flow cytometry, and after pretreating HDFs through

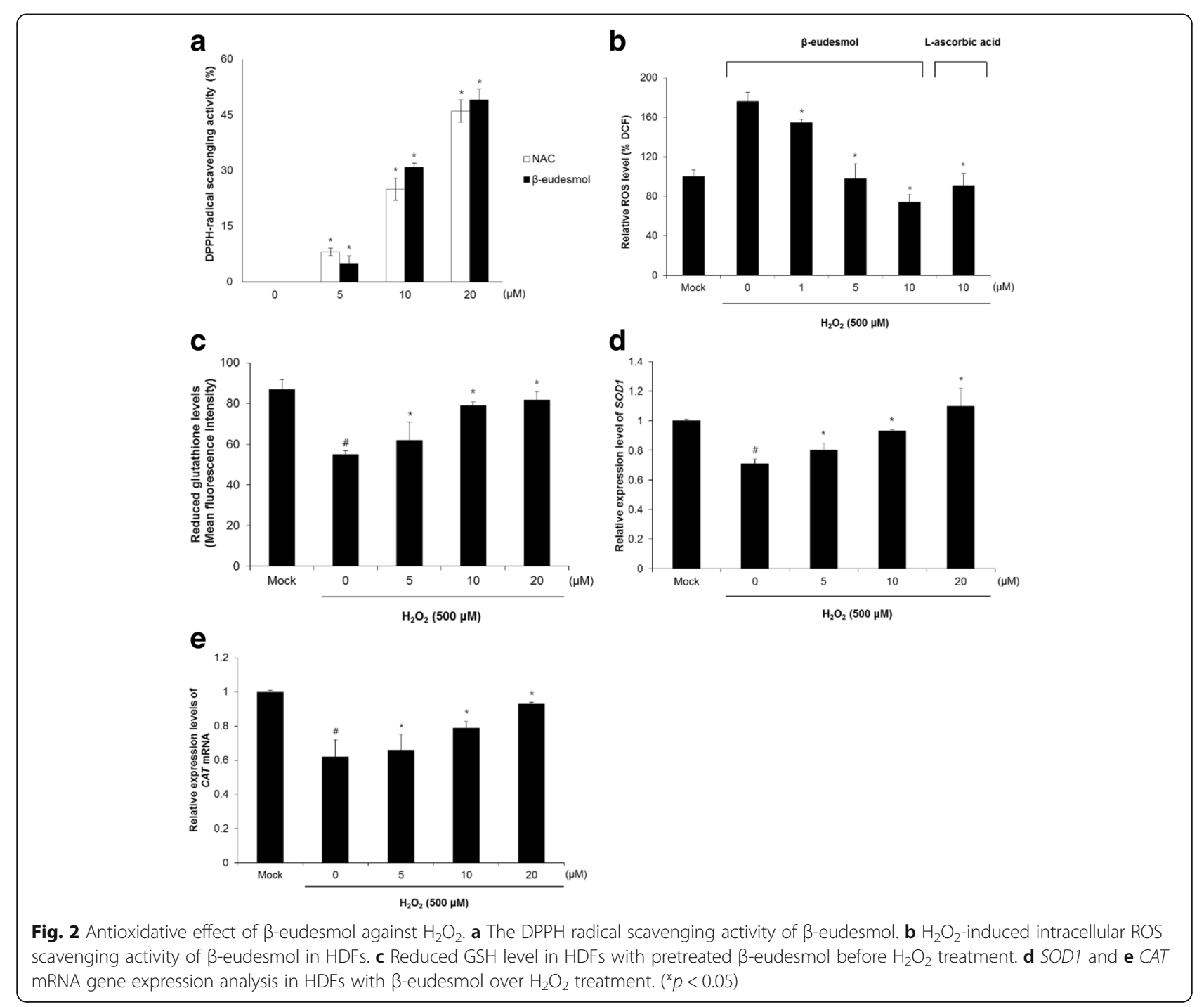


$\beta$-eudesmol for $24 \mathrm{~h}$, we treated HDFs through $\mathrm{H}_{2} \mathrm{O}_{2}$ of $500 \mu \mathrm{M}$. Its results which we analyzed after $3 \mathrm{~h}$ are as follows: Assuming it is $100 \%$, in that case, we did not treat HDFs through both $\beta$-eudesmol and $\mathrm{H}_{2} \mathrm{O}_{2}$, total amount of ROS increased to $176 \%$ at the case of treatment through $\mathrm{H}_{2} \mathrm{O}_{2}$. However, at the case of treatment through $\beta$ eudesmol in each concentration of 1,5 , and $10 \mu \mathrm{M}$, it was identified that the total amount of ROS decreases to 155, 98, and $74 \%$ respectively. At the case of L-ascorbic acid as the positive control group, total amount of ROS was shown as $91 \%$ when we treated in concentration of $10 \mu \mathrm{M}$. This result is similar to the case of treatment through $\beta$ eudesmol in concentration of $5 \mu \mathrm{M}$; therefore, we identified that $\beta$-eudesmol has an effect on decrease of total amount of intracellular ROS (Fig. 2b). Using the principle that ROS lowers intracellular GSH level through oxidative reaction or reaction to thiol group, we used Violet dye which reacts to thiol group to identify the glutathione level reduced form. As for the result that we pretreated HDFs through $\beta$ eudesmol for $24 \mathrm{~h}$ and then treated through $\mathrm{H}_{2} \mathrm{O}_{2}$ of $500 \mu \mathrm{M}$ and analyzed $3 \mathrm{~h}$ later, when we treated nothing, GSH level was shown as 87, but at the case of treatment through $\mathrm{H}_{2} \mathrm{O}_{2}$, it decreases to 55 . However, at the case of pretreatment through $\beta$-eudesmol in each concentration of 5,10 , and $20 \mu \mathrm{M}$, GSH level increased to 62,79 , and 82 respectively; therefore, we identified that both results were similar to each other and GSH levels recovered at the same level (Fig. 2c). To identify antioxidation effects of $\beta$ eudesmol at a gene level, we identified changing of antioxidation enzyme SOD1 gene expression through qRT-PCR. Assuming SOD1 gene expression level is 1 at the case of no treatment for both $\beta$-eudesmol and $\mathrm{H}_{2} \mathrm{O}_{2}, \mathrm{SOD} 1$ gene expression decreased to 0.71 at the case of treatment through $\mathrm{H}_{2} \mathrm{O}_{2}$. However, when we pretreated through $\beta$-eudesmol in each concentration of 5,10 , and $20 \mu \mathrm{M}$ for $24 \mathrm{~h}$, treated through $\mathrm{H}_{2} \mathrm{O}_{2}$, and then analyzed $3 \mathrm{~h}$ later, $\mathrm{SOD} 1$ gene expression increased to $0.8,0.93$, and 1.1 respectively. Through this result, we were able to identify that $\beta$ eudesmol increased SOD1 gene expression to have an influence on antioxidation effects in this experiment (Fig. 2d). Catalase (CAT) as the antioxidation enzyme has a role as catalyst to react to intracellular $\mathrm{H}_{2} \mathrm{O}_{2}$ and extinct radical to change into $\mathrm{H}_{2} \mathrm{O}$. To identify antioxidation effects of $\beta$ eudesmol, we checked changing of catalase gene, CAT expression. Assuming CAT gene expression level is 1 at the case of no treatment through both $\beta$-eudesmol and $\mathrm{H}_{2} \mathrm{O}_{2}$, CAT gene expression decreased to 0.62 at the case of treatment through $\mathrm{H}_{2} \mathrm{O}_{2}$. However, when we pretreated through $\beta$-eudesmol in each concentration of 5,10 , and $20 \mu \mathrm{M}$ and then treated through $\mathrm{H}_{2} \mathrm{O}_{2}$, CAT gene expression increased to $0.66,0.79$, and 0.93 respectively as per a dose-dependent manner of $\beta$-eudesmol. Through this result, we identified that $\beta$-eudesmol increased $C A T$ gene expression to have intracellular antioxidation effects (Fig. 2e).

\section{Anti-inflammatory effects of $\beta$-eudesmol}

Through NF-kB luciferase assay, we identified promoter activity of NF-kB, the transcription factor. We used NIH-3T3 stable cell line including luciferase gene which contains NF$\mathrm{kB}$ promoter consensus sequence in the field of promoter, added luciferin which reacts to luciferase to form fluorescer, and estimated the amount of luciferase gene expression through luciferin luminance estimation. When we treated through $\mathrm{H}_{2} \mathrm{O}_{2}$, luminance of luciferin increased to 7.9 times compared with control group which were non-treated with HDFs, but when we treated through $\mathrm{H}_{2} \mathrm{O}_{2}$ after pretreating $\beta$-eudesmol in a concentration of $5 \mu \mathrm{M}$, it decreased to 5.7 times. At the case of pretreatment through $\beta$-eudesmol in a concentration of $10 \mu \mathrm{M}$ and treatment through $\mathrm{H}_{2} \mathrm{O}_{2}$, it decreased to 3.1 times; at the case of pretreatment through $\beta$ eudesmol in a concentration of $20 \mu \mathrm{M}$ and treatment through $\mathrm{H}_{2} \mathrm{O}_{2}$, it decreased to 2.8 times; therefore, we identified that luciferin luminance decreased depending on the concentration of $\beta$-eudesmol. Therefore, we identified that $\beta$-eudesmol hindered transcriptional activity of NF- $\mathrm{kB}$ (Fig. 3a). We checked changing of $I L-1 \beta$ gene expression which is related to early inflammation reaction. $I L-1 \beta$ gene expression increased to 9.2 times when we treated through $\mathrm{H}_{2} \mathrm{O}_{2}$ than when we did not treat through both $\beta$-eudesmol and $\mathrm{H}_{2} \mathrm{O}_{2}$. However, when we pretreated through $\beta$ eudesmol in a concentration of $5 \mu \mathrm{M}$ and then treated through $\mathrm{H}_{2} \mathrm{O}_{2}$, the amount of $I L-1 \beta$ gene expression depending on concentrations of $\beta$-eudesmol decreased to 7.3 times. At the case of pretreatment through $\beta$-eudesmol in a concentration of $10 \mu \mathrm{M}$ and treatment through $\mathrm{H}_{2} \mathrm{O}_{2}$, it decreased to 3.1 times; at the case of pretreatment through $\beta$ eudesmol in a concentration of $20 \mu \mathrm{M}$ and treatment through $\mathrm{H}_{2} \mathrm{O}_{2}$, it decreased to 2.4 times (Fig. 3b). Subsequently, after we pretreated HDFs through $\beta$-eudesmol in each concentration for $24 \mathrm{~h}$ and treated through $\mathrm{H}_{2} \mathrm{O}_{2}$ for $3 \mathrm{~h}$, we analyzed changing of TNF- $\alpha$ gene expression. When we treated $\mathrm{HDFs}$ through $\mathrm{H}_{2} \mathrm{O}_{2}$, it increased to 6.6 times comparing with the control group which we did not treat through both $\beta$-eudesmol and $\mathrm{H}_{2} \mathrm{O}_{2}$. However, when we pretreated through $\beta$-eudesmol in a concentration of $5 \mu \mathrm{M}$ for $24 \mathrm{~h}$ and then treated through $\mathrm{H}_{2} \mathrm{O}_{2}$, the amount of $T N F-\alpha$ gene expression depending on concentration of $\beta$ eudesmol decreased to 4.9 times; at the case of pretreatment through $\beta$-eudesmol in concentration of $10 \mu \mathrm{M}$ for $24 \mathrm{~h}$ and treatment through $\mathrm{H}_{2} \mathrm{O}_{2}$, it decreased to 3.1 times; and at the case of pretreatment through $\beta$-eudesmol in concentration of $20 \mu \mathrm{M}$ for $24 \mathrm{~h}$ and treatment through $\mathrm{H}_{2} \mathrm{O}_{2}$, it decreased to 2.3 times (Fig. 3c).

\section{Cellular senescence and extracellular matrix (ECM) modulation gene expression analysis of $\beta$-eudesmol}

SA $\beta$-gal assay is particularly observed in senescent cells and is largely used as an indicator of senescence (Dimri et al. 1995). When we did not treat HDFs through both 

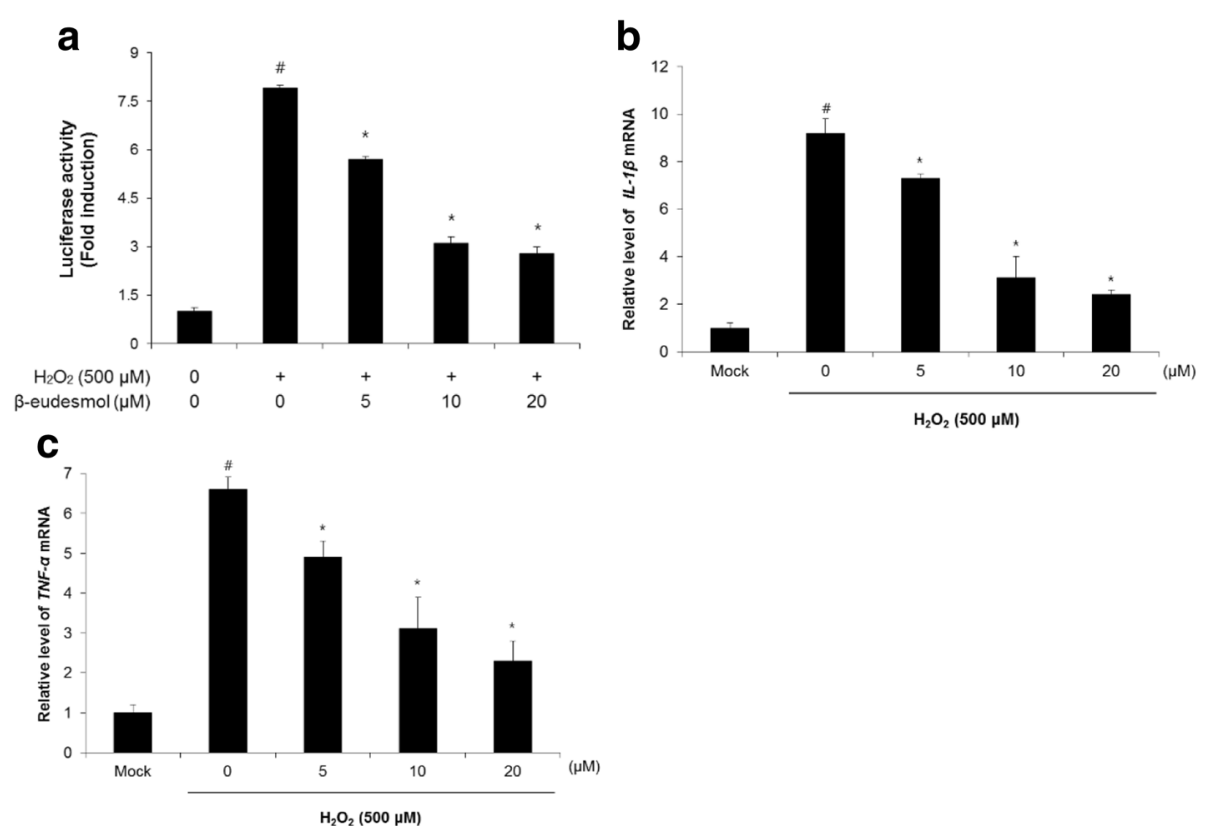

Fig. 3 Anti-inflammatory effect of $\beta$-eudesmol against $\mathrm{H}_{2} \mathrm{O}_{2}$ in $\mathrm{HDFs}$. a Analysis of NF-KB promoter luciferase activity on $\mathrm{H}_{2} \mathrm{O}_{2}$-treated $\mathrm{HDFs}$, pretreated with $\beta$-eudesmol. b $I L-1 \beta$ and c TNF- $a$ mRNA gene expression levels on $\mathrm{H}_{2} \mathrm{O}_{2}$ HDFs, pretreated with $\beta$-eudesmol. Gene expression was evaluated using qRT-PCR with the $2^{-\Delta \Delta C t}$ method and data presented were normalized to $\beta$-actin. $\left({ }^{*} p<0.05\right)$

$\beta$-eudesmol and $\mathrm{H}_{2} \mathrm{O}_{2}, \quad \beta$-galactosidase activity was shown as 6, and at the case of treatment through $\mathrm{H}_{2} \mathrm{O}_{2}$, it increased to 69 -folds. However, when we pretreated through $\beta$-eudesmol in a concentration of $5 \mu \mathrm{M}$ for $24 \mathrm{~h}$ and then treated through $\mathrm{H}_{2} \mathrm{O}_{2}, \beta$-galactosidase activity depending on concentration of $\beta$-eudesmol decreased and was shown as 51 ; at the case of pretreatment through $\beta$-eudesmol in a concentration of $10 \mu \mathrm{M}$ for $24 \mathrm{~h}$ and treatment through $\mathrm{H}_{2} \mathrm{O}_{2}$, it was shown as 27; and at the case of pretreatment through $\beta$-eudesmol in a concentration of $20 \mu \mathrm{M}$ for $24 \mathrm{~h}$ and treatment through $\mathrm{H}_{2} \mathrm{O}_{2}$, it was shown as 18 (Fig. 4a). We used qRT-PCR method to identify changing of COL1A1 gene expression which forms type I collagen constituting 80 to $85 \%$ of collagen. The relative COL1A1 gene expression decreased to 0.39 at the case of treatment of $\mathrm{H}_{2} \mathrm{O}_{2}$ compared with non-treated cells. However, we identified that COL1A1 gene expression increases depending on concentration of $\beta$-eudesmol, as the result that at the case of pretreatment through $\beta$-eudesmol in a concentration of $5 \mu \mathrm{M}$ and treatment through $\mathrm{H}_{2} \mathrm{O}_{2}$, it was shown as 0.54; at the case of pretreatment through $\beta$-eudesmol in a concentration of $10 \mu \mathrm{M}$ and treatment through $\mathrm{H}_{2} \mathrm{O}_{2}$, it was shown as 0.72; and at the case of pretreatment through $\beta$-eudesmol in a concentration of $20 \mu \mathrm{M}$ and treatment through $\mathrm{H}_{2} \mathrm{O}_{2}$, it was shown as 0.88 (Fig. 4c). To identify changing of $M M P 1$ gene expression which decomposes type I collagen constituting most of dermis, we used qRT-PCR method to identify influence of $\beta$ - eudesmol on dermal tissue. When we did not treat HDFs through both $\beta$-eudesmol and $\mathrm{H}_{2} \mathrm{O}_{2}, M M P 1$ gene expression was 0.51 , and $M M P 1$ gene expression was doubled to be shown as 1 at the case of treatment through $\mathrm{H}_{2} \mathrm{O}_{2}$. However, we identified that MMP1 gene expression decreases depending on concentration, as the result that at the case of pretreatment through $\beta$ eudesmol in a concentration of $5 \mu \mathrm{M}$ and treatment through $\mathrm{H}_{2} \mathrm{O}_{2}$, it was 0.84 ; at the case of pretreatment through $\beta$-eudesmol in a concentration of $10 \mu \mathrm{M}$ and treatment through $\mathrm{H}_{2} \mathrm{O}_{2}$, it was 0.69 ; and at the case of pretreatment through $\beta$-eudesmol in a concentration of $20 \mu \mathrm{M}$ and treatment through $\mathrm{H}_{2} \mathrm{O}_{2}$, it was 0.58. Particularly, MMP1 gene expression at the case of treatment through $\beta$-eudesmol in a concentration of $20 \mu \mathrm{M}$ was similar to the result at the case of no treatment (Fig. 4c). We identified changing of TIMP1 (Fisher Jr and Zheng 1996; Enjoji et al. 2000) gene expression which is a hindrance factor to MMP1 and MMP9 to identify its influence on collagen metabolism. Assuming TIMP1 gene expression is 1 when we did not treat HDFs through both $\beta$-eudesmol and $\mathrm{H}_{2} \mathrm{O}_{2}$, TIMP1 gene expression decreased to 0.3 sharply at the case of treatment through $\mathrm{H}_{2} \mathrm{O}_{2}$. However, when we pretreated through $\beta$-eudesmol in a concentration of $5 \mu \mathrm{M}$ and then treated though $\mathrm{H}_{2} \mathrm{O}_{2}$, TIMP1 gene expression depending on concentration increased to be shown as 0.35 ; at the case of pretreatment through $\beta$-eudesmol in a concentration of $10 \mu \mathrm{M}$ and treatment through $\mathrm{H}_{2} \mathrm{O}_{2}$, it 

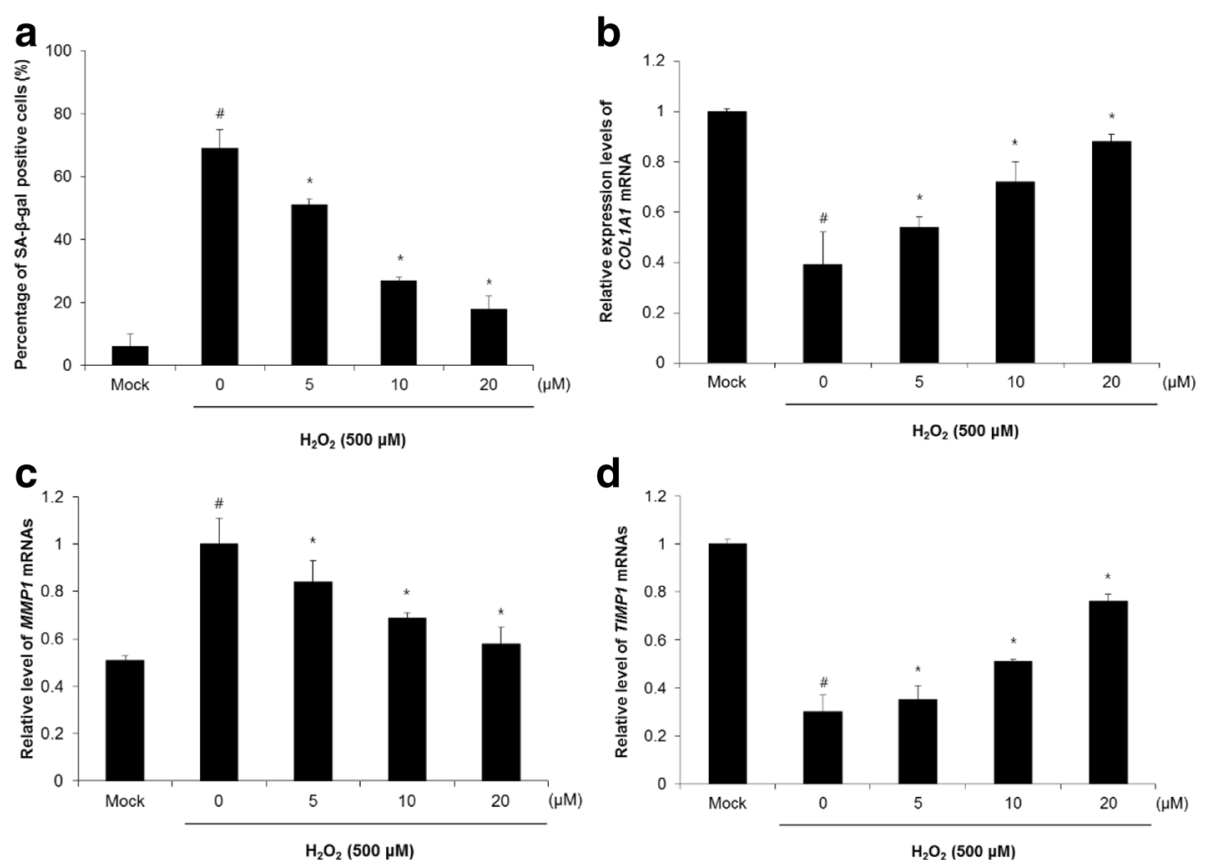

Fig. 4 Senescence attenuation effect of $\beta$-eudesmol against $\mathrm{H}_{2} \mathrm{O}_{2}$ in $\mathrm{HDFs}$. a Protective effect of $\beta$-eudesmol on $\mathrm{H}_{2} \mathrm{O}_{2}$-induced cellular senescence in HDFs using SA- $\beta$-gal assay. b COLIA1, c MMP1, and $\mathbf{d}$ TIMP1 mRNA gene expression levels on $\mathrm{H}_{2} \mathrm{O}_{2}$-treated HDFs, pretreated with $\beta$-eudesmol. Gene expression was evaluated using qRT-PCR with the $2^{-\Delta \Lambda C t}$ method and data presented were normalized to $\beta$-actin. $\left({ }^{*} p<0.05\right)$

was 0.51 ; and at the case of pretreatment through $\beta$ eudesmol in a concentration of $20 \mu \mathrm{M}$ and treatment through $\mathrm{H}_{2} \mathrm{O}_{2}$, it was 0.76 (Fig. 4d).

\section{Discussion}

\section{Antioxidation effects of $\beta$-eudesmol}

When human skin is under oxidative stress caused by ROS, DNA, lipid, and protein damage can occur (Devasagayam and Kamat 2002). When intracellular ROS increases, through various intracellular signal transmission processes, it hinders collagen synthesis and promotes MMP expression which is an enzyme to decompose collagen to accelerate causing wrinkles and skin aging (Lavker and Kaidbey 1997). Also oxidative stress is deeply related to not only skin aging but also inflammation reaction so that it has an influence on controlling activity of various kinds of cells. If inflammation reaction is not controlled well, sometimes it will lead to a reaction to accelerate senescence (De Martinis et al. 2005).

To minimize damage caused by ROS, our body uses antioxidation enzymes such as SOD, CAT, and glutathione peroxidase (GPX) which are our defense mechanisms or methods to supply antioxidation substances such as vita$\min$ (Vit) C, Vit E, and ubiquinone into our body, and research on development of antioxidation substances has been in progress continuously (Choi et al. 2007). In this research, we used $\beta$-eudesmol to apply to HDFs and identified its possibility as an antioxidant suitable for skin.
Through experimental methods such as DPPH radical activity assay, ROS quantitative analysis using DCF-DA, GSH estimation, SOD1 gene expression, and CAT gene expression, we verified antioxidation effects of $\beta$ eudesmol. As the result of experiment through DPPH radical activity assay, we identified that radical extinction effects increase depending on concentration of $\beta$ eudesmol and that similar radical extinction effects appear comparing the case of $\mathrm{N}$-acetyl-L-cysteine, the positive control group; therefore, we identified there were radical extinction effects. Although we identified antioxidation effects of $\beta$-eudesmol sample through DPPH radical activity assay, we also identified intracellular antioxidation effects through ROS quantitative analysis using DCF-DA and GHS estimation. The total amount of intracellular ROS in HDFs decreased depending on concentration of $\beta$-eudesmol, and particularly at the case of treatment through $\beta$-eudesmol in a concentration of $5 \mu \mathrm{M}$, it showed a similar result to a positive control group which we treated through L-ascorbic acid used as antioxidation effect marker in a concentration of $10 \mu \mathrm{M}$; therefore, it was considered that $\beta$-eudesmol had an effect to remove ROS. To identify effects of $\beta$-eudesmol to extinct intracellular $\mathrm{H}_{2} \mathrm{O}_{2}$ and hinder $\mathrm{OH}^{-}$radical formation, we used a GSH measurement analysis method. As an indicator of toxicity reaction which induces apoptotic effect and oxidative stress, changing of GSH level has been estimated (Esposito et al. 2000; Zhang et al. 
2010; Kil et al. 2012). It was identified that GSH level increased in accordance with an increase in concentration of $\beta$-eudesmol.

When human skin is under oxidative stress, signal transmission system is activated, in which cells react, increase radical formation, and decrease antioxidation enzyme expression (Masaki et al. 1995; Barber et al. 1998; Yasui and Sakurai 2000; Yamamoto and Gaynor 2001). To verify antioxidation effects of $\beta$-eudesmol at the gene level, we identified changing of antioxidation enzyme $S O D 1$ and $C A T$ gene expression. It was identified that $S O D 1$ and $C A T$ gene expression increased depending on concentration of $\beta$-eudesmol. Based on the above results, it was identified that $\beta$-eudesmol had not only antioxidation effects mediated with biological enzymes but also radical extinction effects with various methods. $\beta$ eudesmol sample itself had antioxidation effects and terminated intracellular ROS effectively. Also it was identified that it decreased antioxidation enzyme expression which is a ROS defense mechanism and controls ROS from the gene level to extinct ROS. Therefore, it was considered that $\beta$-eudesmol had hindrance effects to various damages and stimulations caused by oxidative stress on human skin (Fig. 5).

\section{Anti-inflammation effects of $\beta$-eudesmol by controlling NF-KB promoter activity}

$\mathrm{NF}-\mathrm{KB}$ is the named transcription factor whose role is identified to be concerned with controlling immunoglobulin kappa chain gene expression in B cells (Sen and Baltimore 1986). Through classical pathway and alternative pathway, NF- $\mathrm{KB}$ has a decisive role of inflammation reaction, immune reaction, cell proliferation, and apoptotic effects in various processes, and it has been identified as a survival factor in various cells against lipopolysaccharide (LPS), cytokine, ROS, and stimulation by ultraviolet (UV) rays (Baeuerle and Henkel 1994; Siebenlist et al. 1994; Kopp and Ghosh 1995; Ghosh et al. 1998; Karin and Delhase 2000). NF-kB is composed of homo or hetero-dimer and formed with five subunits

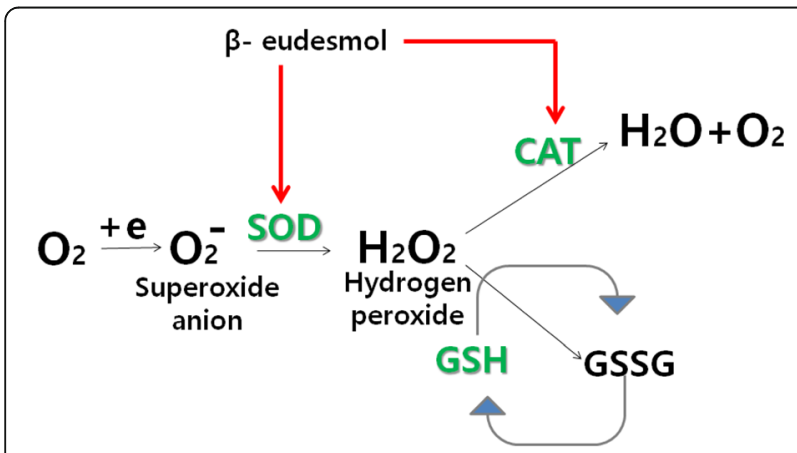

Fig. 5 Mechanism of $\beta$-eudesmol on how it regulates antioxidant genes transcriptional levels against oxidative stress in HDFs such as p65 (RelA), RelB, c-Rel, p50 (NF-кB 1), and p52 (NF-kB 2) (Gilmore 2006). NF- $\mathrm{kB}$ is combined with inhibitor of NF- $\mathrm{KB}(\mathrm{I} \kappa \mathrm{B})$ to exist in the cytoplasm with its state of deactivation, but IKB kinase (IKK) is activated through stimulation of UV rays or ROS on cells and phosphorylates IкB to be separated. Phosphorylated IкB is decomposed by ubiquitination and separated from proteasome, and NF- $\mathrm{kB}$ flows into the nucleus and works as a transcription factor (Ghosh and Karin 2002; He and Karin 2011). TNF- $\alpha$, IL, and chemokine, which are a product of inflammatory precursor, have a role to mediate an important course of cell activities such as cell proliferation, angiogenesis, and metastasis. Transcription of gene expression within which these molecules are coded is controlled by NF- $\kappa B$ (Gloire et al. 2006). Through intracellular signal transmission, NF- $\mathrm{kB}$ controls various cell metabolism, but in that case, it works as transcription factor of inflammation-mediated substances and it promotes transcription of COX2, Eselectin, inducible nitric oxide synthase (iNOS), intercellular adhesion molecule-1 (ICAM-1), IL-6, IL-12, IL-1 $\beta$, MMP, TNF- $\alpha$, and vascular cell adhesion molecular 1 (VCAM-1) to accelerate inflammation reaction and cause tissue damage (Limuro et al. 1997; Bukman et al. 1998; Chen et al. 1999; Suschek et al. 2004; Yamamoto and Gaynor 2001; Farooqui et al. 2007).

To identify that influence of $\beta$-eudesmol on control of NF- $\kappa B$ activity which has a significant role in inflammation reaction, we used NF- $\mathrm{KB}$ luciferase assay method to identify NF- $\kappa B$ activity, and it was found that NF- $\kappa B$ activity decreased depending on concentration of $\beta$-eudesmol. In this experiment, we examined effects to hinder NF- $\mathrm{KB}$, and also, we checked changing of downstream gene expression which increases through NF- $\mathrm{KB}$ activation. Through a qRT-PCR method, we checked changing of gene expression of cytokine IL-1 $\beta$, TNF- $\alpha$ (Fisher Jr and Zheng 1996; Dinarello 1991) which is a representative medium of early inflammation reaction. It was identified that $I L-1 \beta, T N F-\alpha$ inflammation induction gene expression decreased as concentration of $\beta$-eudesmol increases. Through this experiment, we identified that $\beta$-eudesmol shut off the NF-kB pathway to hinder $I L-1 \beta, T N F-\alpha$ gene expression and inflammation reaction.

\section{Regulation mechanism of ECM gene expression of $\beta$ - eudesmol}

Increase in ROS within dermal tissue has an influence on intracellular transforming growth factor-beta (TGF$\beta)$ cytokine, activator protein 1 (AP-1) transcription factor, NF- $\mathrm{kB}$ transcription factor, and signal transmission pathway of Smad3/4; controls collagen formation gene expression; and increases gene expression of MMPs which is an enzyme-decomposing collagen so that it causes changing of ECM tissue and skin aging (Lee et al. 
2012; Varani et al. 2002; Saito et al. 2004). AP-1, NF-kB, and Smad from increase in ROS are activated by MAPK which works as an intracellular signal transmission factor. MAP-kinase p38, JNK, and extracellular signalregulated kinase (ERK) exist in MAPK, and MAPK is concerned with various intracellular mechanisms such as cell growth, division, apoptosis, and gene expression (Kohl et al. 2011). When MAPK is activated by ROS, it activates NF- $\mathrm{kB}$ to increase $M M P$ gene expression and induce collagen decomposition (Lee et al. 2012; Bae et al. 2008). Moreover, it induces AP-1 activation, enters into cell nucleus, works as transcription factor to promote $M M P 1, M M P 3$, and $M M P 9$ gene expression, and hinders COL1A1 gene expression (Quan et al. 2005; Lee et al. 2006). Increase in ROS causes hindering TGF- $\beta$ which is a bifidus factor to control transcription activity of Smad (Leivonen and Kähäri 2007). Collagen gene expression which is one of their downstream genes is regulated and it induces collapse of ECM tissue within dermis to cause wrinkle, loss of elasticity, and skin aging (Quan et al. 2005). Within the dermis, TIMP which is an enzyme-hindering MMP activity, exists and with MMPs forms one to one complex to hinder MMP enzyme, and there are TIMP1, TIMP2, TIMP3, and TIMP4 as kinds of TIMP (Gomis-Rüth et al. 1997). MMP1 and MMP9 are enzymes which decompose type I collagen constituting $85 \%$ of collagen in the dermis, and it is TIMP1 enzyme which hinders MMP1 and MMP9 (Enjoji et al. 2000; Fisher et al. 1999). With its complicated mechanism, TIMPs control MMP activity, and when the balance between them is lost, it sometimes leads to tumor, and it has been reported that its gene expression increases through epidermal growth factor (EGF), TNF- $\alpha$, IL-1, and TGF- $\beta$ (Birkedal-Hansen 1993; Lee et al. 2016; Jang and Lee 2016).

Through changing of signal transmission process and gene expression of $\beta$-eudesmol in ECM, we identified its effects on human dermal fibroblast preservation and cell activation. Through experimental results, we identified that it controlled NF- $\mathrm{kB}$ activity, and we checked changing of COL1A1, MMP1 gene expression which are downstream genes of NF-кB. COL1A1 gene expression increased as concentration of $\beta$-eudesmol increased, and MMP1 gene expression decreased depending on the concentration of $\beta$-eudesmol. We identified that TIMP1 gene expression which hindered MMP1 increases depending on the concentration of $\beta$-eudesmol. Taking these experimental results together, it is identified that $\beta$-eudesmol shuts off the NF- $\mathrm{kB}$ pathway to regulate $M M P 1$ gene expression and that COL1A1 gene expression increases as the concentration of $\beta$-eudesmol increases. According to existing researches related to COL1A1 gene expression, when AP-1 is activated by ROS, it promotes $M M P 1, M M P 3$, and $M M P 9$ gene expression and hinders COL1A1 gene expression (Quan et al. 2005; Lee et al. 2006). Also, it has been reported that ROS hinders a bifidus factor such as TGF- $\beta$ to regulate transcription activity of Smad (Leivonen and Kähäri 2007) and control collagen gene expression which is a downstream gene (Quan et al. 2005). Therefore, it is considered that by $\beta$-eudesmol, AP-1 activity is hindered to regulate $M M P 1, M M P 3$, and $M M P 9$ gene expression, that $\beta$-eudesmol increases COL1A1 gene expression and activates TGF- $\beta$, and that COL1A1 gene expression increases through transcription activity of Smad. Through this experimental result, it is considered that $\beta$-eudesmol preserves tissue within the dermis and has effects to promote ECM formation to protect dermal cells. It has been identified that $\beta$-eudesmol has effects on cell preservation within the dermis at the gene level, but to find out whether this result proves effects to regulate cell senescence actually, through SA- $\beta$-gal assay experimental method, we identified human dermal fibroblast cell senescence. As for the experimental result of SA- $\beta$-gal assay, $\beta$-galactosidase activity decreased depending on concentration of $\beta$-eudesmol. Namely, it is found that $\beta$ eudesmol has effects to regulate cell senescence. Therefore, it is considered that $\beta$-eudesmol is highly useful as a cosmetic compound because it has antioxidation and anti-inflammation effects, delays dermal cell senescence, and has cell preservation effects (Fig. 6).

\section{Conclusions}

In conclusion, the present study showed that $\beta$-eudesmol has several effects on anti-inflammatory and ECM constructed gene expression in human dermal fibroblasts. Our results represented the antioxidant effect of $\beta$-eudesmol through improving intracellular antioxidant molecule and gene expressions, scavenging excessive generated ROS, and

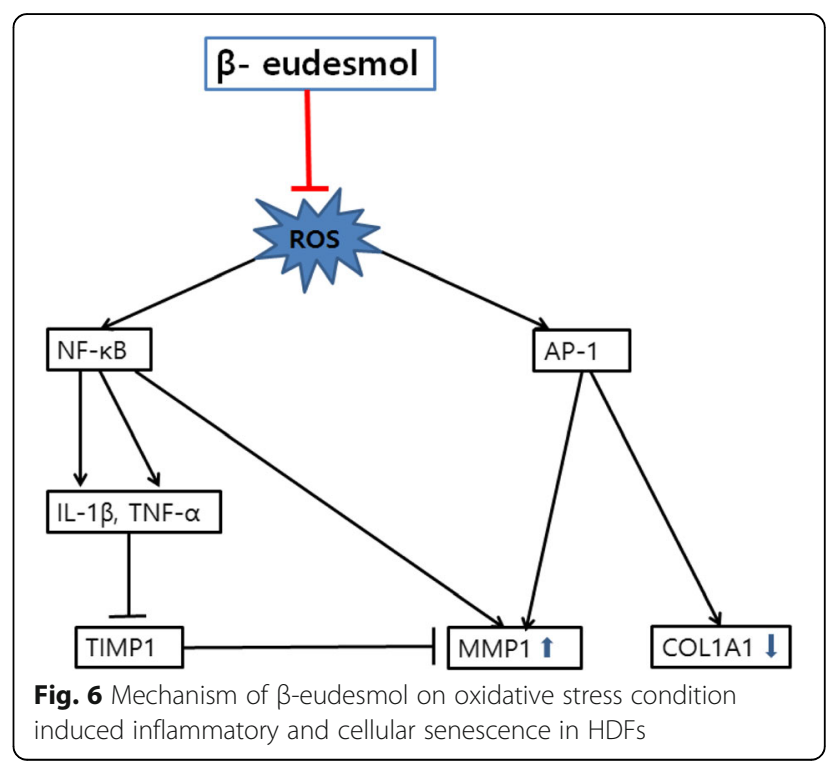


radical scavenging capacity. Based on the above antioxidant results, we identified protective effect of $\beta$-eudesmol on NF-kB-mediated inflammatory signaling activities. These preliminary results provided an interesting point in HDF: $\beta$-eudesmol may have impediment action to aging. Thus, SA- $\beta$-gal assay and ECM-related gene expression analysis were conducted, which suggested effective senescencehindering capacity of $\beta$-eudesmol in dermal fibroblast cells. Additional further studies, in vitro and in vivo, will be necessary to verify molecular pathways and mechanisms of $\beta$-eudesmol in detail, but this study suggests $\beta$-eudesmol as a "cosmeceutical" compound.

\section{Abbreviations \\ AP-1: Activator protein 1; CAT: Catalase; COL1A1: Collagen, type I, alpha 1; DCF-DA: 2',7'-Dichlorofluorescin diacetate; DEPC: Diethylpyrocarbonate; DMEM: Dulbecco's modified Eagle's medium; DMF: Dimethylformamide; DMSO: Dimethyl sulfoxide; DPPH: 2,2-Diphenyl-1-picrylhydrazyl; \\ ECM: Extracellular matrix; EGF: Epidermal growth factor; ERK: Extracellular signal-regulated kinase; FBS: Fetal bovine serum; GPX: Glutathione peroxidase; GSH: Glutathione; HDF: Human dermal fibroblast; ICAM- 1: Intercellular adhesion molecule-1; IKK: IKB kinase; IL-12: Interleukin 12; IL- 1B: Interleukin 1 beta; IL-6: Interleukin 6; iNOS: Inducible nitric oxide synthase; JNK: c-Jun N-terminal kinases; LPS: Lipopolysaccharide; MAPK: Mitogen- activated protein kinase; MMP: Matrix metalloproteinase; NAC: N-Acetyl-L- cysteine; NF-kB: Nuclear factor-kappa B; PC12: Pheochromocytoma; PBS: Phosphate buffered saline; qRT-PCR: Quantitative real-time polymerase chain reaction; ROS: Reactive oxygen species; SA- $\beta$-gal: Senescence- associated beta-galactosidase; SOD1: Superoxide dismutase 1; TIMP1: Tissue inhibitors of metalloproteinases-1; TNF-a: Tumor necrosis factor-alpha; TGF- B: Growth factor-beta; WST-1: Water-soluble tetrazolium salt; VCAM- \\ 1: Vascular cell adhesion molecular 1; Vit C: Vitamin C}

\section{Acknowledgements}

The author thanks all the study subjects and research staff who participated in this work.

\section{Funding}

Not applicable

\section{Availability of data and materials}

Not applicable

\section{Author's contributions}

KYK did all of research background such as experiments, data collecting, and statistical analysis as well as drafting the manuscript.

\section{Ethics approval and consent to participate}

Not applicable

\section{Consent for publication}

Not applicable

\section{Competing interests}

The author declares no competing interests.

\section{Publisher's Note}

Springer Nature remains neutral with regard to jurisdictional claims in published maps and institutional affiliations.

Received: 11 July 2017 Accepted: 19 December 2017 Published online: 20 January 2018

\section{References}

Bae JY, Choi JS, Choi y, Shin SY, Kang SW, Han SJ, Kang YH. (-)Epigallocatechin gallate hampers collagen destruction and collagenase activation in
ultraviolet-B-irradiated human dermal fibroblasts: involvement of mitogenactivated protein kinase. Food Chem Toxicol. 2008;46:1298-307.

Baeuerle PA, Henkel T. Function and activation of NF-kappa B in the immune system. Annu Rev Immunol. 1994:12:141-79.

Barber LA, Spandau DF, Rathman SC, Murphy RC, Johnson CA, Kelley SW, et al. Expression of the platelet-activating receptor results in enhanced ultraviolet $\mathrm{B}$ radiation-induced apoptosis in a human epidermal cell line. J Biol Chem. 1998;273:18891-7.

Birkedal-Hansen $\mathrm{H}$. Role of matrix metalloproteinases in human periodontal disease. J Periodontol. 1993;64(Suppl 5):474-84.

Bukman SY, Gresham A, Hale P, Hruze G, Anast J, Masferrer J, et al. COX-2 expression is induced by UVB exposure in human skin: implications for the development of skin cancer. Carcinogenesis. 1998;19:723-9.

Chen F, Castranova V, Shi X, Demers LM. New insights into the role of nuclear factor-kappa B, a ubiquitous transcription factor in the initiation of diseases. Clin Chem. 1999;45:7-17.

Chiou LC, Chang CC. Antagonism by $\beta$-eudesmol of neostigmine-induced neuromuscular failure in mouse diaphragms. Eur J Pharmacol. 1992;216:199-206.

Chiou LC, Ling JY, Chang CC. B-Eudesmol as an antidote for intoxication from organophosphorus anticholinesterase agents. Eur J Pharmacol. 1995;292:151-6.

Chiou LC, Ling JY, Chang CC. Chinese herbs constituent $\beta$-eudesmol alleviated the electroshock seizures in mice and electrographic seizures in rat hippocampal slices. Neurosci Lett. 1997;231:171-4.

Choi CW, Jung HA, Kang SS, Choi JS. Antioxidant constituents and a new triterpenoid glycoside from Flos Lonicerae. Arch Parm Res. 2007;30:1-7.

De Martinis M, Franceschi C, Monti D, Ginaldi L. Inflamma-ageing and lifelong antigenic load as major determinants of ageing rate and longevity. FEBS Lett. 2005;579:2035-9.

Devasagayam TP, Kamat JP. Biological significance of singlet oxygen. Indian J Exp Biol. 2002:40:680-92

Dimri GP, Lee X, Basile G, Acosta M, Scott G, Roskelley C, et al. A biomarker that identifies senescent human cells in culture and in aging skin in vivo. Proc Natl Acad Sci U S A. 1995;92:9363-7.

Dinarello CA. The proinflammatory cytokines interleukin-1 and tumor necrosis factor and treatment of the septic shock syndrome. J Infect Dis. 1991;163:1177-84.

Enjoji M, Kotoh K, Iwamoto H, Nakamuta M, Nawata H. Self-regulation of type collagen degradation by collagen-induced production of matrix metalloproteinase-1 on cholangiocarcinoma and hepatocellular carcinoma cells. In Vitro Cell Dev Biol Anim. 2000;36:71-3.

Esposito LA, Kokoszka JE, Waymire KG, Cottrell B, MacGregor GR, Wallace DC. Mitochondrial oxidative stress in mice lacking the glutathione peroxidase-1 gene. Free Radic Biol Med. 2000;28:754-66.

Farooqui AA, Horrocks LA, Farooqui T. Modulation of inflammation in the brain; a matter of fat. J Neurochem. 2007;101:577-99.

Fisher GJ, Talwar HS, Voorhees JJ. Molecular mechanism of photoaging in human skin in vivo and their prevention by all trans retinoic acid. Photochem Photobiol. 1999:69:154-7.

Fisher CJ Jr, Zheng Y. Potential strategies for inflammatory mediator manipulation: retrospect and prospect. World J Surg. 1996;20:447-53.

Ghosh S, Karin M. Missing pieces in the NF-KB puzzle. Cell. 2002;109(Suppl 1):S81-96.

Ghosh S, May MJ, Kopp EB. NF-KB and Rel proteins: evolutionarily conserved mediators of immune responses. Annu Rev Immunol. 1998;16:255-60.

Gilmore TD. Introduction to NFkappaB: players, pathways, perspectives. Oncogene. 2006;25:6680-4.

Gloire G, Legrand-Poels S, Piette J. NF-KB activation by reactive oxygen species: fifteen years later. Biochem Pharmacol. 2006;72:1493-505.

Gomis-Rüth FX, Maskos K, Betz M, Bergner A, Huber R, Suzuki K, et al. Mechanism of inhibition of the human matrix metalloproteinase stromelysin-1 by TIMP-1. Nature. 1997;389:77-81.

He G, Karin M. NF-KB and STAT3 - key players in liver inflammation and cancer. Cell Res. 2011;21:159-68.

Hoang DM, Trung TN, He L, Ha DT, Lee MS, Kim BY. Eudesmols induce apoptosis through release of cytochrome c in HL-60 cells. Nat Prod Sci. 2010;16:88-92.

Ikeda K, Nagase H. Magnolol has the ability to induce apoptosis in tumor cells. Biol Pharm Bull. 2002;25:1546-9.

Jang HH, Lee SN. Epidermal skin barrier. Asian J Beauty Cosmetol. 2016;14:339-47.

Karin M, Delhase M. The IKB kinase (IKK) and NF-KB: key elements of proinflammatory signalling. Semin Immunol. 2000;12:85-98.

Kil IS, Lee SK, Ryu KW, Woo HA, Hu MC, Bae SH, et al. Feedback control of adrenal steroidogenesis via $\mathrm{H}_{2} \mathrm{O}_{2}$-dependent, reversible inactivation of peroxiredoxin III in mitochondria. Mol Cell. 2012;46:584-94. 
Kimura M, Kimura I, Kondoh T, Tsuneki H. Noncontractile acetylcholine receptoroperated ca++ mobilization: suppression of activation by open channel blockers and acceleration of desensitization by closed channel blockers in mouse diaphragm muscle. J Pharmacol Exp Ther. 1991;256:18-23.

Kohl E, Steinbauer J, Landthaler M, Szeimies RM. Skin ageing. J Eur Acade Dermatol Venereol. 2011;25:873-84.

Kopp EB, Ghosh S. NF-kB and rel proteins in innate immunity. Adv Immunol. 1995;58:1-27.

Lavker R, Kaidbey K. The spectral dependence for UVA-induced cumulative damage in human skin. J Invest Dermatol. 1997;108:17-21.

Lee J, Jung E, Lee J, Huh S, Hwang CH, Lee HY, et al. Emodin inhibits TNF alphainduced MMP-1 expression through suppression of activator protein-1 (AP-1). Life Sci. 2006;79:2480-5.

Lee S, Han HS, An IS, Ahn KJ. Effects of amentoflavone on anti-inflammation and cytoprotection. Asian J Beauty Cosmetol. 2016;14:201-11.

Lee YR, Noh EM, Han JH, Kim JM, Hwang BM, Cung EY, et al. Brazilin inhibits UVBinduced MMP-1/3 expressions and secretions by suppressing the NF-KB pathway in human dermal fibroblast. Eur J Pharmacol. 2012;674:80-6.

Leivonen SK, Kähäri VM. Transforming growth factor- $\beta$ signaling in cancer invasion and metastasis. Int J Cancer. 2007;121:2119-24.

Li Y, Li T, Miao C, Li J, Xiao W, Ma E. $\beta$-Eudesmol induces JNK-dependent apoptosis through the mitochondrial pathway in HL60 cells. Phytother Res. 2013;27:338-43

Lim DY, Kee YW. Infuence of $\beta$-eudesmol on blood pressure. Nat Prod Sci. 2005; 11:33-40.

Limuro Y, Gallucci RM, Luster MI, Kono H, Thurman RG. Antibodies to tumor necrosis factor alfa attenuate hepatic necrosis and inflammation caused by chronic exposure to ethanol in the rat. Hepatology. 1997;26:1530-7.

Ma EL, Li YC, Tsuneki H, Xiao JF, Xia MY, Wang MW, et al. $\beta$-Eudesmol suppresses tumour growth through inhibition of tumour neovascularisation and tumour cell proliferation. J Asian Nat Prod Res. 2008;10:159-68.

Masaki H, Atsumi T, Sakurai H. Detection of hydrogen peroxide and hydroxyl radicals in murine skin fibroblasts under UVB irradiation. Biochem Biophys Res Commun. 1995;206:474-9.

Miyazawa M, Shimamura H, Nakamura SI, Kameoka H. Antimutagenic activity of (+)- $\beta$-eudesmol and paeonol from Dioscorea japonica. J Agric Food Chem. 1996:44:1647-50

Obara Y, Aoki T, Kusano M, Ohizumi Y. $\beta$-Eudesmol induces neurite outgrowth in rat pheochromocytoma cells accompanied by an activation of mitogen activated protein kinase. J Pharmacol Exp Ther. 2002;301:803-11.

Plengsuriyakarn T, Karbwang J, Na-Bangchang K. Anticancer activity using positron emission tomography-computed tomography and pharmacokinetics of $\beta$-eudesmol in human cholangiocarcinoma xenografted nude mouse model. Clin Exp Pharmacol Physiol. 2015;42:293-304.

Quan T, He T, Voorhees JJ, Fisher GJ. Ultraviolet irradiation induces Smad7 via induction of transcription factor AP-1 in human skin fibroblasts. J Biol Chem. 2005;280:8079-85.

Saito Y, Shiga A, Yoshida Y, Furuhashi T, Fujita Y, Niki E. Effects of a novel gaseous antioxidative system containing a rosemary extract on the oxidation induced by nitrogen dioxide and ultraviolet radiation. Biosci Biotechnol Biochem. 2004;68:781-6.

Satoh K, Nagai F, Ushiyama K, Yasuda I, Akiyama K, Kano I. Inhibition of Na+, K(+)ATPase activity by $\beta$-eudesmol, a major component of atractylodis lanceae rhizoma, due to the interaction with enzyme in the Na.E1 state. Biochem Pharmacol. 1992;44:373-8.

Sen R, Baltimore D. Multiple nuclear factors interact with the immunoglobulin enhancer sequences. Cell. 1986;46:705-16.

Seo MJ, Kim SJ, Kang TH, Rim HK, Jeong HJ, Um JY. The regulatory mechanism of $\beta$-eudesmol is through the suppression of caspase-1 activation in mast cellmediated inflammatory response. Immunopharm Immunot. 2011;33:178-85.

Siebenlist U, Franzoso G, Brown K. Structure, regulation and function of NF-kB. Annu Rev Cell Biol. 1994;10:405-55.

Suschek CV, Mahotka C, Schnorr o, Kolb-Bachofen V. UVB radiation-mediated expression of inducible nitric oxide synthase activity and the augmenting role of co-induced TNF-alpha in human skin endothelial cells. J Invest Dermatol. 2004;123:950-7.

Varani J, Perone P, Fligiel SE, Fisher GJ, Voorhees JJ. Inhibition of type I procollagen production in photodamage: correlation between presence of high molecular weight collagen fragments and reduced procollagen synthesis. J Invest Dermatol. 2002;119:122-9.

Watanabe K, Goto Y, Yoshitomi K. Central depressant effects of the extracts of magnolia cortex. Chem Pham Bull. 1973;21:1700-8.
Watanabe K, Watanabe H, Goto Y, Yamaguchi N, Yamamoto N, Hagino K. Pharrmacologocal properties of magnolol and honokiol extracted from Magnolia officinalis: central depressant effects. Planta Med. 1983;49:103-8.

Yamamoto Y, Gaynor RB. Therapeutic potential of inhibition of the NF- KB pathway in the treatment of inflammation and cancer. J Clin Invest. 2001; 107:135-42.

Yasui $H$, Sakurai $H$. Chemiluminescent detection and imaging of reactive oxygen species in live mouse skin exposed to UVA. Biochem Biophys Res Commun. 2000;269:131-6.

Zhang Y, Zhang HM, Shi Y, Lustgarten M, Li Y, Qi W, et al. Loss of manganese superoxide dismutase leads to abnormal growth and signal transduction in mouse embryonic fibroblasts. Free Radic Biol Med. 2010;49:1255-62.

\section{Submit your next manuscript to BioMed Central and we will help you at every step:}

- We accept pre-submission inquiries

- Our selector tool helps you to find the most relevant journal

- We provide round the clock customer support

- Convenient online submission

- Thorough peer review

- Inclusion in PubMed and all major indexing services

- Maximum visibility for your research

Submit your manuscript at www.biomedcentral.com/submit
C) Biomed Central 